3 Research Square

\title{
The traditional medicinal use of some animals and their products in Wolaita, Southern Ethiopia
}

\author{
Abenezer Wendimu \\ Wolaita Sodo University \\ Wondimagegnehu Tekalign ( $\nabla$ wondimagegnehubeyene@gmail.com ) \\ Wolaita Sodo University https://orcid.org/0000-0002-4721-7528
}

\section{Research Article}

Keywords: Ethnopharmacology, Popular medicine, Homegrown knowledge, Medicinal animals

Posted Date: August 26th, 2021

DOI: https://doi.org/10.21203/rs.3.rs-846799/v1

License: (c) (i) This work is licensed under a Creative Commons Attribution 4.0 International License. Read Full License 


\section{Abstract}

Ethnopharmacological relevance: From the beginning of recorded history, flora and fauna have played a crucial part in human existence for a therapeutic purpose to heal different diseases and are still being used in Ethiopia. Ethnozoological studies are necessary so as to get new medications for human and livestock health ailments. There is a sense of urgency in gathering such information. This is the first ethnozoological survey to do statistical calculations on animal-based treatments.

Aim of the study: The present study aimed to identify, analyze and record traditional knowledge on the use of animals by the indigenous people living on Diguna Fango district, Wolaita, Ethiopia, and to document the traditional names, preparation, and uses of these animals for therapeutic purpose.

Materials and methods: A field survey was carried out from March 2021 to June 2021 by personal interviews through semi-structured questionnaires and open group discussions. Two hundred male and female informants gave information concerning the therapeutic uses of various animal parts/products.

Results: For the treatment of 159 identified different ailments, thirty-nine animal parts/products were utilized. Mammals were the topmost use report, followed by arthropods and avian species.

Conclusions: The outcomes showed that there's the highest ethnozoological knowledge to be recognized which could be of use in emerging innovative drugs. As a result, it is predicted that the information contained in the study will be utilized in the region's forthcoming ethnozoological, ethnopharmacological, and conservation-related research.

\section{Introduction}

Ethiopia is blessed with a rich collection of floral and faunal resources that are helpful to humans in a variety of ways. Oil, wood, and many different agricultural plants, as well as many different animal species, contribute to the rich ecosystems that sustain a diverse range of life forms. Throughout history, humans have relied on nature for their fundamental needs such as medicines, shelters, food, perfumes, clothing, tastes, fertilizers, and modes of transportation (Wendimu and Tekalign, 2020; Wendimu et al., 2021).

According to Lev and Amar (2000), animals and their parts and products have been utilized as medicine in various civilizations since prehistoric times. In 1993, the World Health Organization reported that animal and plant-based medications were used by the majority of the world's population (WHO, 1993). Of the 252 health-promoting necessary chemicals that are selected by the WHO, 8.7\% are products of animal resources (Alves et al., 2007).

The majority of individuals in Sub-Saharan Africa believe traditional medicines and Traditional Health Practitioners (THPs) as their primary source of health care (Keter and Mutiso, 2012, Wendimu et al., 2021). It is estimated that traditional medicine is used by more than $80 \%$ of Ethiopia's rural population (Endashaw, 2007; Alevtina and Zerihun, 2009; Elias et al., 2013, Wendimu et al., 2021).

The medicinal uses of animal species were identified therapeutically to prepare remedies and treat different ailments in different corners of Ethiopia (Kendie et al., 2018). Among those animals that were used therapeutically were mammals, reptiles, and birds (Dereje and Chane, 2014). However, most of the ethnobiological studies conducted in Ethiopia have focused on traditional knowledge of plants (Hailemariam, 2009; Giday, 2010; Regassa 2013; Assegid and Tesfaye, 2014; Melesse et al. 2015; Tuasha et al. 2018; Tefera and Kim 2019; Wendimu et al., 2021). A little work has been wiped out ethnozoology and particularly no work is documented within the Diguna Fango district and there's a particular scarcity of ethnobiological knowledge when it comes to animal products. Thus, the current investigation indicated an ethnozoological study from the Diguna Fango district, Wolaita, Ethiopia.

\section{Materials And Methods}

\subsection{Study area description}

The investigation was conducted in seven adjacent kebeles (the smallest administration unit) within the lower Fango cluster of the Diguna Fango district from March 2021 to June 2021. The selection was carried out based on the accessibility of traditional healers. The district is located at $6^{\circ} 577^{\prime} 571^{\prime \prime} \mathrm{N}$ $38^{\circ} 02^{\prime} 15.7^{\prime \prime} \mathrm{E}$. The altitudinal range of the study area is between 1395 m.a.s.l. and 2070 m.a.s.l. The study area is found $350 \mathrm{~km}$ south of Addis Ababa, Ethiopia, and $93 \mathrm{~km}$ away from Sodo town, Wolaita. Diguna Fango is bordered by Damot Weyde, Damot Gale districts on the southwest and the west, Hadiya zone on the north, and by Oromia on the northeast, and Sidama regions on the east. The average annual rainfall and temperature of the area are approximately $700 \mathrm{~mm}$ and $21^{\circ} \mathrm{C}$, respectively.

\subsection{Sampling and data collection}

To collect data about the ethnomedicinal use of animals, 35 volunteers have participated in field surveys. They were grouped into five sections (five volunteers in one group). Each group carried out the field survey in the selected kebeles as assigned by the supervisor. The data collectors were taken enough training before starting the field survey. The ethnomedicinal data about the use of animals and their products were collected utilizing the participatory rural appraisal (PRA) technique, which entails an interview, informal meeting, and open group discussions with semi-structured questionnaires, with the informants, also serving as investigators (Alexiades, 1996; Huntington, 2000; Kim and Song, 2011). The informants were chosen based on their traditional therapeutic experience, recognition as experts, and knowledge of old aged people concerning the preparation of traditional medicine.

The informants were asked, particularly the illnesses healed by animal-based remedies and the way in which the medicines were prepared and administered. The respondents were also asked about the mode of preparation and amalgamation of animal products used as ingredients, as well as whether or not they 
use animals in their healing practice, because this type of data indicates how a given medicine is frequently therapeutically effective in terms of the proper ingredients, the right dose, and thus the right length of medication. The local name and scientific name of animals and detailed ingredients of medicine whether they use only animal parts or mixed with other ingredients like plant material were also noted (Ali, 1996; Bekele and Yalden, 2013).

\subsubsection{Group discussion}

The discussion was made on the significance of animals in traditional medicine and related issues with the selected informants of the study site. During the discussions, an attempt was made to encourage the healers in such a way that their cooperation would be of benefit to the country, and at the same time, informed consent was obtained before data collection.

\subsubsection{Semi-structured interviews}

Prior to the interview, a semi-structured checklist and interview questions were prepared. The interviews backed up the checklist, and a few issues were raised quickly based on an informant's response.

\subsection{Data analysis}

The data were collected through a semi-structured questionnaire, interview, and group discussion. To analyze the collected data Excel for window 2019 was utilized in addition to other appropriate statistical tools such as frequency distribution and percentage. 2

\subsubsection{Fidelity level (FL)}

The fidelity level is useful for determining the inhabitants' favorite species for treating specific ailments. During this study, the FL values varied from 1.0$100 \%$. Generally, an FL of $100 \%$ for a specific animal indicates that all of the use reports mentioned the same method for using the animal for treatment (Kim and Song, 2013).

\section{Results}

\subsection{The demographic characteristics of informants}

The present study identified the traditional medicinal knowledge of treating various kinds of ailments using different animals and their parts/products by local inhabitants of different kebeles of Diguna Fango district, Wolaita, Ethiopia. Throughout the field study, 125 male and 75 female informants participated in the interview and group discussion. Ninety-four (47\%) informants were with the age of 55 and above, 73 (36.5\%) within the age range of 45 to 54 , and also 33 (16.5\%) were within the age group of 35-44 years. Due to lack of awareness, access to modern education, and remoteness of educational institutions, most of the people in the study area were lack formal education. As of the total respondents, 104 respondents were illiterate and the remaining 96 are attended at least primary school either in regular or extension programs.

\subsection{Medicinal animals, parts, and products}

Thirty-nine animal species were identified for the treatment of various human and livestock ailments that were used as traditional medicines in the study area (Table 1). The mammalian species were highly reported $(N=26,66.67 \%)$, which is followed by arthropods $(N=5,12.81 \%)$. Besides, avian species $(N=4$, $10.26 \%)$, reptiles $(N=3,7.7 \%)$, and fishes $(N=1,2.56 \%)$ were reported they can be used in the traditional remedy preparation practices in the study area (Fig. 1). 
Table 1

Medicinal animals, there parts and products for traditional therapeutic purposes by the people inhabiting Diguna Fango, Wolaita, Ethiopia

\begin{tabular}{|c|c|c|c|c|c|c|c|c|c|}
\hline No. & Category & $\begin{array}{l}\text { Common } \\
\text { name }\end{array}$ & Local name & Scientific name & Parts used & Preparation & Applications & Aliments & FL \\
\hline \multirow[t]{7}{*}{1.} & \multirow[t]{7}{*}{ Mammals } & \multirow[t]{7}{*}{ Warthog } & \multirow{2}{*}{$\begin{array}{l}\text { Gaashuwa (W), } \\
\text { Kerkero (A) }\end{array}$} & \multirow[t]{2}{*}{$\begin{array}{l}\text { Phacochoerus } \\
\text { africanus }\end{array}$} & \multirow[t]{2}{*}{ Meat } & \multirow[t]{2}{*}{ Cooked } & \multirow[t]{2}{*}{ Oral } & $\begin{array}{l}\text { Bacterial } \\
\text { infections }\end{array}$ & 51 \\
\hline & & & & & & & & Rheumatism & 66 \\
\hline & & & & & \multirow{2}{*}{$\begin{array}{l}\text { Spur, } \\
\text { Stirrup }\end{array}$} & \multirow[t]{2}{*}{ Warm } & \multirow[t]{2}{*}{ Topical } & Breast pain & 47 \\
\hline & & & & & & & & Swelling & 55 \\
\hline & & & & & Teeth & Warm & Topical & Breast pain & 43 \\
\hline & & & & & $\begin{array}{l}\text { Whole } \\
\text { animal }\end{array}$ & Soup & Oral & $\begin{array}{l}\text { Bacterial } \\
\text { infections }\end{array}$ & 44 \\
\hline & & & & & & & & Common cold & 69 \\
\hline \multirow[t]{11}{*}{2.} & \multirow[t]{11}{*}{ Mammals } & \multirow[t]{11}{*}{ Porcupine } & Quxarssaa (W), & \multirow[t]{11}{*}{ Hystrix cristata } & \multirow[t]{7}{*}{ Meat } & \multirow[t]{7}{*}{ Roasted } & \multirow[t]{7}{*}{ Oral } & Weight gain & 64 \\
\hline & & & \multirow[t]{6}{*}{ Jart (A) } & & & & & $\begin{array}{l}\text { Bacterial } \\
\text { infections }\end{array}$ & 64 \\
\hline & & & & & & & & Stomach pain & 68 \\
\hline & & & & & & & & Pleurisy & 60 \\
\hline & & & & & & & & Stunting & 77 \\
\hline & & & & & & & & Rheumatism & 59 \\
\hline & & & & & & & & Swelling & 54 \\
\hline & & & & & Bone & Fumigation & Nasal & Malaise & 57 \\
\hline & & & & & Whole & Soup & Oral & Paralysis & 57 \\
\hline & & & & & & & & Stunting & 48 \\
\hline & & & & & Bile & Raw & Oral & Pleurisy & 73 \\
\hline \multirow[t]{20}{*}{3.} & \multirow[t]{20}{*}{ Mammals } & \multirow[t]{4}{*}{ Cow } & Miizzaa (W), & \multirow[t]{4}{*}{ Bos Taurus } & \multirow[t]{4}{*}{ Milk } & \multirow[t]{4}{*}{ Raw } & Oral & Gastritis & 91 \\
\hline & & & $\operatorname{Lam}(\mathrm{A})$ & & & & & Typhoid fever & 66 \\
\hline & & & & & & & & Weight gain & 76 \\
\hline & & & & & & & & Toxin & 90 \\
\hline & & & & & Spleen & Raw & Oral & Pleurisy & 85 \\
\hline & & & & & & & & Sciatica & 64 \\
\hline & & & & & Liver & Raw & Oral & Anemia & 78 \\
\hline & & & & & Bile & Raw & Oral & Fever & 77 \\
\hline & & & & & Butter & Cooked & Oral & Pleurisy & 66 \\
\hline & & & & & & & & Common cold & 81 \\
\hline & & & & & & & & Bone fractures & 80 \\
\hline & & & & & & & & Weight gain & 76 \\
\hline & & & & & Butter & Raw & Holding & Teeth pain & 77 \\
\hline & & & & & & & & Ear pain & 57 \\
\hline & & & & & Butter & Raw & Topical & Headache & 88 \\
\hline & & & & & Pancreas & Raw & Oral & Sciatica & 85 \\
\hline & & & & & Milk & Churned & Oral & Energy gain & 90 \\
\hline & & & & & & & & Teeth strength & 82 \\
\hline & & & & & Cheese & Cooked & Oral & Stomach pain & 69 \\
\hline & & & & & Rumen & Warm & Oral & Skin disease & 66 \\
\hline
\end{tabular}

Key words: $\mathrm{A}=$ Amharic, $\mathrm{W}=$ Wolatic 


\begin{tabular}{|c|c|c|c|c|c|c|c|c|c|}
\hline No. & Category & $\begin{array}{l}\text { Common } \\
\text { name }\end{array}$ & Local name & Scientific name & Parts used & Preparation & Applications & Aliments & $\mathrm{FL}$ \\
\hline & & & & & & & & Swelling & 54 \\
\hline & & & & & Digestive & Raw & Oral & Fever & 80 \\
\hline & & & & & & & & Throat cancer & 65 \\
\hline & & & & & Leg & Decoction & Oral & Slipped disc & 100 \\
\hline & & & & & & & & Bone fractures & 90 \\
\hline & & & & & & & & Common cold & 88 \\
\hline \multirow[t]{6}{*}{4.} & \multirow[t]{6}{*}{ Mammals } & \multirow[t]{6}{*}{ Donkey } & Hariya (W), & \multirow{6}{*}{$\begin{array}{l}\text { Equus } \\
\text { africanus } \\
\text { asinus }\end{array}$} & \multirow[t]{3}{*}{ Milk } & \multirow[t]{3}{*}{ Raw } & \multirow[t]{3}{*}{ Oral } & Asthma & 67 \\
\hline & & & Ahiya (A) & & & & & Pleurisy & 43 \\
\hline & & & & & & & & Pneumonia & 47 \\
\hline & & & & & Excrement & Raw & Oral & Cold in chicken & 33 \\
\hline & & & & & \multirow[t]{2}{*}{ Excrement } & \multirow[t]{2}{*}{ Raw } & \multirow[t]{2}{*}{ Nasal } & Sinusitis & 35 \\
\hline & & & & & & & & Bronchitis & 43 \\
\hline \multirow[t]{3}{*}{5.} & \multirow[t]{3}{*}{ Mammals } & \multirow[t]{3}{*}{ Human } & $\begin{array}{l}\text { Asaa (W), } \\
\text { Sew (A) }\end{array}$ & \multirow[t]{3}{*}{ Homo sapiens } & $\begin{array}{l}\text { Breast } \\
\text { milk }\end{array}$ & Raw & Topical & Eye disease & 30 \\
\hline & & & & & Urine & Raw & Dropping & Wound & 52 \\
\hline & & & & & Hair & Fumigation & Nasal & Evil eye (ghoul) & 97 \\
\hline \multirow[t]{3}{*}{6.} & \multirow[t]{3}{*}{ Mammals } & \multirow[t]{3}{*}{ Ethiopian hare } & $\begin{array}{l}\text { Harbbaynnuwa } \\
\text { (W), }\end{array}$ & \multirow[t]{3}{*}{ Lepus fagani } & Fur & Raw & Topical & Wound (burnt) & 100 \\
\hline & & & Tinchel (A) & & & & & & \\
\hline & & & & & Meat & Roasted & Oral & $\begin{array}{l}\text { Stunting in } \\
\text { children }\end{array}$ & 98 \\
\hline \multirow[t]{7}{*}{7.} & \multirow[t]{7}{*}{ Mammals } & \multirow[t]{7}{*}{ Spotted hyena } & $\begin{array}{l}\text { Godariya (W), } \\
\text { Jib (A) }\end{array}$ & $\begin{array}{l}\text { Crocuta } \\
\text { crocuta }\end{array}$ & Tongue & Dried & Oral & Evil eye & 78 \\
\hline & & & & & \multirow[t]{3}{*}{ Excrement } & \multirow[t]{3}{*}{ Raw } & \multirow[t]{3}{*}{ Oral } & Evil eye & 53 \\
\hline & & & & & & & & Sciatica & 57 \\
\hline & & & & & & & & Stomach pain & 22 \\
\hline & & & & & Sole & Raw & Holding & Running problem & 12 \\
\hline & & & & & Eye lash & Raw & Holding & Over sleeping & 19 \\
\hline & & & & & Teeth & Raw & Topical & Lymphadenopathy & 33 \\
\hline 8. & Mammals & Sheep & Dorssaa (W), & Ovis aries & Blood & Raw & Oral & Anemia & 55 \\
\hline & & & $\operatorname{Beg}(A)$ & & & & & & \\
\hline & & & & & Milk & Raw & Oral & Asthma & 34 \\
\hline & & & & & & & & Cold & 67 \\
\hline & & & & & Meat & Roasted & Oral & Weight gain & 98 \\
\hline 9. & Mammals & Goat & Deeshshaa (W), & Capra & Milk & Raw & Oral & Fever & 69 \\
\hline & & & Fiyel (A) & hircus & & & & Tropical diseases & 76 \\
\hline & & & & & & & & Energy gain & 88 \\
\hline & & & & & Blood & Raw & Oral & Anemia & 87 \\
\hline & & & & & Excrement & Raw & Topical & Mumps & 60 \\
\hline 10. & Mammals & Bat & Wurkkaawurkkuwa & Cynopterus & Blood & Raw & Topical & Skin disease & 88 \\
\hline & & & Yelelitwnf $(A)$ & & Meat & Raw & Topical & Skin disease & 75 \\
\hline
\end{tabular}




\begin{tabular}{|c|c|c|c|c|c|c|c|c|c|}
\hline No. & Category & $\begin{array}{l}\text { Common } \\
\text { name }\end{array}$ & Local name & Scientific name & Parts used & Preparation & Applications & Aliments & $\mathrm{FL}$ \\
\hline \multirow[t]{6}{*}{11.} & \multirow[t]{6}{*}{ Mammals } & \multirow[t]{6}{*}{ Dog } & & \multirow{6}{*}{$\begin{array}{l}\text { Canis } \\
\text { familaries }\end{array}$} & \multirow[t]{2}{*}{ Tongue } & \multirow[t]{2}{*}{ Raw } & \multirow[t]{2}{*}{ Oral } & Rabies & 32 \\
\hline & & & Wusha (A) & & & & & Gastritis & 10 \\
\hline & & & & & \multirow[t]{4}{*}{ Urine } & \multirow[t]{4}{*}{ Raw } & \multirow[t]{4}{*}{ Topical } & Eye disease & 15 \\
\hline & & & & & & & & Ear pain & 13 \\
\hline & & & & & & & & Skin disease & 9 \\
\hline & & & & & & & & Wart & 31 \\
\hline \multirow[t]{2}{*}{12.} & \multirow[t]{2}{*}{ Mammals } & \multirow[t]{2}{*}{ Monitor lizard } & Wakkallaa (W), & \multirow[t]{2}{*}{ Varanus spp. } & \multirow[t]{2}{*}{ Skin } & \multirow[t]{2}{*}{ Raw } & \multirow[t]{2}{*}{ Tying } & Cold & 41 \\
\hline & & & Arjano (A) & & & & & Rheumatism & 43 \\
\hline \multirow[t]{2}{*}{13.} & \multirow[t]{2}{*}{ Mammals } & \multirow[t]{2}{*}{ Rat } & Eceriya (W), & Rattus spp. & Meat & Cooked & Oral & Stomach pain & 77 \\
\hline & & & Ayt (A) & & & & & & \\
\hline \multirow[t]{4}{*}{14.} & \multirow[t]{4}{*}{ Mammals } & \multirow[t]{4}{*}{ Baboon } & Geleshshuwa (W), & \multirow[t]{4}{*}{ Papio anubis } & \multirow[t]{3}{*}{ Excrement } & \multirow[t]{3}{*}{ Raw } & \multirow[t]{3}{*}{ Oral } & Fever & 44 \\
\hline & & & \multirow[t]{3}{*}{ Zinjero (A) } & & & & & Eye disease & 43 \\
\hline & & & & & & & & Evil eye & 52 \\
\hline & & & & & Urine & Raw & Oral & Fever & 13 \\
\hline 15. & Mammals & Bushbuck & $\begin{array}{l}\text { Gaaraa }(W), \\
\text { Yedur fiyel }(A)\end{array}$ & $\begin{array}{l}\text { Artiodactyla } \\
\text { spp. }\end{array}$ & Meat & Cooked & Oral & Cold & 33 \\
\hline 16. & Mammals & Hippopotamus & $\begin{array}{l}\text { Xadiya (W), } \\
\text { Gumare (A) }\end{array}$ & $\begin{array}{l}\text { Hippopotamus } \\
\text { amphibious }\end{array}$ & Meat & Soup & Topical & Skin disease & 25 \\
\hline 17. & Mammals & Camel & $\begin{array}{l}\text { Gaameelaa (W), } \\
\text { Gimel (A) }\end{array}$ & $\begin{array}{l}\text { Camelus } \\
\text { dromedarius }\end{array}$ & Milk & Raw & Oral & Cold & 73 \\
\hline 18. & Mammals & Serval cat & $\begin{array}{l}\text { Bo"uwa (W), } \\
\text { Dalganbesa (A) }\end{array}$ & $\begin{array}{l}\text { Leptailurus } \\
\text { serval }\end{array}$ & Excrement & Raw & Oral & Fever & 36 \\
\hline 19. & Mammals & Squirrel & $\begin{array}{l}\text { Guppalliya (W), } \\
\text { Shekako (A) }\end{array}$ & Xerus inauris & Meat & Cooked & Oral & Heart disease & 43 \\
\hline 20. & Mammals & Aardvark & $\begin{array}{l}\text { Babbanttaa (W), } \\
\text { Awaldgessa (A) }\end{array}$ & $\begin{array}{l}\text { Orycteropus } \\
\text { afer }\end{array}$ & Excrement & Raw & Nasal & Evil eye & 37 \\
\hline & & & & & Excrement & Raw & Oral & Stomach pain & 17 \\
\hline & & & & & Excrement & Raw & Topical & Skin disease & 42 \\
\hline & & & & & & & & Sore & 36 \\
\hline 21. & Mammals & Pig & $\begin{array}{l}\text { Gudunttaa (W), } \\
\text { Asama (A) }\end{array}$ & Sus scrofa & Meat & Cooked & Oral & Fever & 44 \\
\hline 22. & Mammals & Gopher & $\begin{array}{l}\text { Occuwaa (W), } \\
\text { Filfel (A) }\end{array}$ & $\begin{array}{l}\text { Thomomys } \\
\text { bottae }\end{array}$ & Teeth & Raw & Tying & Swelling & 36 \\
\hline 23. & Mammals & Cat & $\begin{array}{l}\text { Gawaraa }(W) \text {, } \\
\text { Dimet }(A)\end{array}$ & $\begin{array}{l}\text { Felis } \\
\text { domesticus }\end{array}$ & Teeth & Raw & Tying & Swelling & 28 \\
\hline & & & & & Fur & Fumigation & Nasal & Evil sprit & 33 \\
\hline 24. & Mammals & Leopard & Zerussa (W), & Panthera & Skin & Dried & Wearing & Joint pain & 55 \\
\hline & & & Aboshemane (A) & & & & Tying & Rheumatism & 43 \\
\hline & & & & & Tongue & Raw & Tying & Tremor & 55 \\
\hline
\end{tabular}




\begin{tabular}{|c|c|c|c|c|c|c|c|c|c|}
\hline No. & Category & $\begin{array}{l}\text { Common } \\
\text { name }\end{array}$ & Local name & Scientific name & Parts used & Preparation & Applications & Aliments & FL \\
\hline 25. & Mammals & Grey squirrel & Parshsholiya (W), & $\begin{array}{l}\text { Sciurus } \\
\text { carolinensis }\end{array}$ & Meat & Decoction & Oral & Trypanosomiasis & 80 \\
\hline 26. & Mammals & Duiker & $\begin{array}{l}\text { Genessaa (W), } \\
\text { Midakuwa (A) }\end{array}$ & $\begin{array}{l}\text { Sy/vicapra } \\
\text { grimmia }\end{array}$ & Skin & Dried & Tying & $\begin{array}{l}\text { Walking problem } \\
\text { in cattle }\end{array}$ & 24 \\
\hline 27. & Arthropods & Dragonfly & $\begin{array}{l}\text { Haattabeexiya }(W) \text {, } \\
\text { Yewuhaterb }(A)\end{array}$ & $\begin{array}{l}\text { Sympetrum } \\
\text { flaveolum }\end{array}$ & $\begin{array}{l}\text { Whole } \\
\text { body }\end{array}$ & Raw & Tying & Swelling & 45 \\
\hline 28. & Arthropods & Scorpion & $\begin{array}{l}\text { Masimasuwa }(W) \\
\text { Gint }(A)\end{array}$ & $\begin{array}{l}\text { Palamnaeus } \\
\text { swammerdami }\end{array}$ & $\begin{array}{l}\text { Whole } \\
\text { body }\end{array}$ & Raw & Topical & Scorpions' toxin & 44 \\
\hline \multirow[t]{6}{*}{29.} & \multirow[t]{6}{*}{ Arthropods } & \multirow[t]{6}{*}{ Honey bee } & \multirow[t]{2}{*}{ Mattaa (W), } & \multirow[t]{6}{*}{ Apis mellifera } & \multirow[t]{3}{*}{ Larvae } & \multirow[t]{3}{*}{ Raw } & \multirow[t]{3}{*}{ Oral } & Pleurisy & 89 \\
\hline & & & & & & & & Stomach pain & 87 \\
\hline & & & \multirow[t]{4}{*}{$\operatorname{Nib}(\mathrm{A})$} & & & & & & \\
\hline & & & & & Honey & Raw & Topical & Skin disease & 77 \\
\hline & & & & & \multirow[t]{2}{*}{ Honey } & \multirow[t]{2}{*}{ Raw } & \multirow[t]{2}{*}{ Oral } & $\begin{array}{l}\text { Erectile } \\
\text { dysfunction (ED) }\end{array}$ & 75 \\
\hline & & & & & & & & Cold & 66 \\
\hline 30. & Arthropods & Tick & $\begin{array}{l}\text { Danqquwa (W), } \\
\text { Mezhiger (A) }\end{array}$ & All tick spp. & Blood & Raw & Topical & Skin disease & 54 \\
\hline 31. & Arthropods & Sweat bee & $\begin{array}{l}\text { Degerra }(W), \\
\text { Tazma }(A)\end{array}$ & $\begin{array}{l}\text { Halictus } \\
\text { scabiosae }\end{array}$ & $\begin{array}{l}\text { Wild } \\
\text { honey }\end{array}$ & Raw & Nasal & Rheumatism & 75 \\
\hline \multirow[t]{4}{*}{32.} & \multirow[t]{4}{*}{ Reptiles } & \multirow[t]{4}{*}{ Python } & Demiya (W), & \multirow[t]{4}{*}{ Python spp. } & \multirow{3}{*}{$\begin{array}{l}\text { Visceral } \\
\text { fat }\end{array}$} & \multirow[t]{4}{*}{ Raw } & \multirow[t]{4}{*}{ Topical } & Rheumatism & 43 \\
\hline & & & \multirow[t]{3}{*}{ Zendo (A) } & & & & & Asthma & 44 \\
\hline & & & & & & & & Headache & 39 \\
\hline & & & & & & & & Skin disease & 22 \\
\hline 33. & Reptiles & Snake & $\begin{array}{l}\text { Shooshshaa (W), } \\
\text { Ebab (A) }\end{array}$ & Naja naja & $\begin{array}{l}\text { Skin } \\
\text { (shed) }\end{array}$ & Raw & Tying & Urinary problems & 9 \\
\hline 34. & Reptiles & Chameleon & $\begin{array}{l}\text { Shaaqanchchaa } \\
(\mathrm{W}), \\
\text { Esist (A) }\end{array}$ & $\begin{array}{l}\text { Chamaeleo } \\
\text { chamaeleon }\end{array}$ & Tongue & Raw & Tying & Swelling of gland & 54 \\
\hline \multirow[t]{2}{*}{35.} & \multirow[t]{2}{*}{ Birds } & \multirow[t]{2}{*}{ Raven } & Qooraasiya (W), & \multirow[t]{2}{*}{ Corvus corax } & \multirow[t]{2}{*}{ Egg } & \multirow[t]{2}{*}{ Raw } & \multirow[t]{2}{*}{ Oral } & HIV & 25 \\
\hline & & & Kura (A) & & & & & Asthma & 36 \\
\hline \multirow[t]{10}{*}{36.} & \multirow[t]{7}{*}{ Birds } & Chicken/Hen & Kuttuwa (W), & Gallus gallus & Egg & Raw & Oral & Cold & 67 \\
\hline & & & Doro (A) & & & & & Sciatica & 45 \\
\hline & & & & & & & & Pleurisy & 36 \\
\hline & & & & & & & & Gastritis & 65 \\
\hline & & & & & & & & Common cold & 77 \\
\hline & & & & & & & & Abdominal pain & 69 \\
\hline & & & & & & & & Fever & 50 \\
\hline & & & & & $\begin{array}{l}\text { Spoiled } \\
\text { egg }\end{array}$ & Raw & Oral & Cold in donkeys & 22 \\
\hline & & & & & $\begin{array}{l}\text { Abdominal } \\
\text { fat }\end{array}$ & Oiled & Dropping & Ear pain & 39 \\
\hline & & & & & $\begin{array}{l}\text { Whole } \\
\text { body }\end{array}$ & Cooked & Oral & Weight gain & 89 \\
\hline
\end{tabular}




\begin{tabular}{|c|c|c|c|c|c|c|c|c|c|}
\hline No. & Category & $\begin{array}{l}\text { Common } \\
\text { name }\end{array}$ & Local name & Scientific name & Parts used & Preparation & Applications & Aliments & $\mathrm{FL}$ \\
\hline & & & & & & & & Cold & 43 \\
\hline & & & & & Excrement & Raw & Oral & Stomach pain & 21 \\
\hline & & & & & Excrement & Raw & Topical & Skin disease & 32 \\
\hline & & & & & & & & Sore (head) & 36 \\
\hline 37. & Birds & Dove & $\begin{array}{l}\text { Haraphphiya (W), } \\
\text { Rigib (A) }\end{array}$ & $\begin{array}{l}\text { Columbiformes } \\
\text { spp. }\end{array}$ & Egg & Raw & Oral & Pleurisy & 64 \\
\hline 38. & Birds & Partridge & $\begin{array}{l}\text { Kuraachchuwa } \\
(\mathrm{W}) \text {, } \\
\text { Jigra (A) }\end{array}$ & Alectoris rufa & Egg & Raw & Oral & Cold & 69 \\
\hline 39. & Fishs & Fish & $\begin{array}{l}\text { Moliya }(W) \text {, } \\
\text { Asa }(A)\end{array}$ & Any fish spp. & $\begin{array}{l}\text { Whole } \\
\text { animal }\end{array}$ & Soup & Oral & Cold & 90 \\
\hline & & & & & Meat & Cooked & Oral & Bone fractures & 78 \\
\hline & & & & & $\begin{array}{l}\text { Whole } \\
\text { animal }\end{array}$ & Oiled & Oral & Bone fractures & 77 \\
\hline & & & & & Liver & Raw & Oral & Eye disease & 43 \\
\hline
\end{tabular}

The cows 11(33.3\%) were reported as the highest number of parts/products used to treat different ailments $(N=21,37.5 \%)$, followed by spotted hyena $(N=$ $5,15 \%)$ used to treat ailments $(N=7,12.5 \%)$. The product/part-wise grouping of animals used as traditional medicine demonstrated the use of various parts and products of the animals in the preparation of traditional remedies for different types of ailments in the study area. For instance, the visceral organs, such as bile, fat, tongue, liver, rumen, spleen, and pancreas, and the animal products, such as milk, butter, cheese, egg, and honey were the highly ranked groups $(N=18,20.45 \%)$. Besides; in the local community, excreta, and urine of some animals, meat, bone/teeth, external body part (leg, skin, sole, fur, hair, eyelash, horn, spur), the whole body, blood, larvae other products were used for the treatment of a particular type of ailments (Table 2).

Table 2

Animal parts or products used to traditional medicine in the study area

\begin{tabular}{|llll|}
\hline No. & Parts/products of animals used as medicine & Citations & Percentage (\%) \\
\hline 1. & Meat & 13 & $15.3 \%$ \\
\hline 2. & Visceral organs (bile, fat, tongue, juices, liver, rumen, spleen, pancreas) & 15 & $17 \%$ \\
\hline 3. & Products (honey, milk, butter, cheese, egg) & 18 & $21.1 \%$ \\
\hline 4. & Bone/teeth & 5 & $5.8 \%$ \\
\hline 5. & External body part (Leg, skin, sole, fur, hair, eye lash, horn, spur) & 12 & $14 \%$ \\
\hline 6. & Excreta (stool and urine) & 10 & $11.7 \%$ \\
\hline 7. & Whole body & 3 & $3.5 \%$ \\
\hline 8. & Blood & 4 & $4.7 \%$ \\
\hline 9. & Larvae & 1 & $1.7 \%$ \\
\hline 10. & Biting & 1 & $1.7 \%$ \\
\hline 11. & Soup & 3 & $3.5 \%$ \\
\hline
\end{tabular}

\subsection{Method of remedy preparation}

The results depict 10 different ways of remedy preparation for the medicinal materials of animals. Raw used medicine occupied $58(65.90 \%)$ of the total preparation, followed by cooked $9(10.23 \%)$, soup 4(4.55\%), fumigation and roasted (each $3.40 \%$ ), warm and dried (each $3.40 \%)$, oiled, and decoction (each $2.27 \%$ ), and churned 1 (1.14\%) (Fig. 2). 


\subsection{Administration route and applications}

The traditional remedies were administrated through different routes. The most frequently used route was oral 50(57\%), followed by topical $18(20 \%)$, tying $9(10 \%)$, nasal 6(7\%), holding 3(3\%), dropping 2(2\%), and wearing $1(1 \%)$ (Fig. 3).

\section{Discussion}

Humans and animals have depended on one other throughout history. Food, medicine, and clothes made from animal parts or products have been used for thousands of years. Research suggests that around 2.5 million years ago, people transitioned from a vegetarian lifestyle to one that included meat in their meals (at the dawn of the genus Homo) (Larsen, 2003, Holzman, 2003). Humans obtained food and raw materials from the wild wildlife and vegetation ten thousand years ago (Serpell, 1996). Other evidence of early human-animal ties can be found in rock paintings that represent wild animals such as bison, horses, and deer being hunted by human beings.

Ethnozoology is concerned with the past and present interactions of human civilizations with animals, which is owing to the fundamental relationships that exist between people and other animals. Human views toward animals, according to Lawrence (2003), evolved long before the first attempts to depict them aesthetically or examine them scientifically. In this respect, it has been proposed that ethnozoology began with the appearance of humans as a species, or, maybe more accurately, with our species' initial encounter with other creatures (Alves and Souto, 2010).

The vast diversity and richness of Africa's faunal resources are well-known. It is home to approximately 2,000 important biodiversity sites and the world's most diversified and numerous big ungulate (hoofed mammal) populations (Ripple et al., 2015, Wolf and Ripple, 2016) and freshwater fishes than any other continent. There are more than 320 species of mammals, 860 species of birds, 200 reptiles, 63 amphibians, and 145 fishes in Ethiopia, according to Bekele and Yalden (2013). Animals of all kinds are utilized for food, clothes, and traditional healthcare practices to treat a variety of human and livestock illnesses, ranging from insect larvae to larger mammalian species.

About $80 \%$ of the human population still depends on traditional medicine in the country Ethiopia (Endashaw, 2007; Alevtina and Zerihun, 2009; Keter and Mutiso, 2012; Elias et al., 2013, Wendimu et al., 2021). In the present study, 39 animals and their parts and products that were believed to be medicine for over 159 kinds of ailments were identified from Diguna Fango district, Wolaita, Ethiopia. The study of Haileselasie (2012) that was done in the Degu tribes in the Northern Tigray region of Ethiopia indicated that 23 animals and their parts were to be used in the form of traditional medicines. Dereje and Chane (2014) were reported that, in the southern part of Ethiopia, a total of 21 animal species were used to prepare remedies for 46 ailments. In the Kafta-Humera district, Northern Ethiopia, 16 species of medicinal animals were collected and identified for treating 18 diverse human ailments (Yirga et al., 2011). In NorthWestern Ethiopia, entirely 51 animal species were recognized to treat 36 diverse ailments (Kendie et al., 2018).

Apart from Ethiopia, South Africa recorded 147 medicinal vertebrate species, including 60 mammalian species, 33 reptile species, 53 bird species, and one amphibian species (Whiting et al., 2010). Oliveira et al. (2010) also described 23 animal species in Brazil that are utilized as traditional medicines. In India, mammals accounted for half of the 36 vertebrate species used in disease treatment (Chakravorty, 2011). There are 108 animal species identified in Pakistan, with $83 \%$ of birds and $17 \%$ of mammals (Altaf et al., 2017). Borah and Brasad (2017) identified 44 animal species in India for the treatment of 40 different diseases. Other discoveries in various regions of the world have identified many vertebrate species that have been used in traditional medicine (ElKamali, 2000; Alves et al., 2010; 2012).

The animals used therapeutically in the present study area were mammalian species $(N=26,66.67 \%), 5(12.81 \%)$, arthropods $(N=4,10.26 \%)$, avian species $(N=3,7.7 \%)$, reptiles and fish $(N=1,2.56 \%)$. A similar study done in Ethiopia indicated that, out of 51 animal species used therapeutically, 27(52.9\%) were mammals, 9(17.6\%) birds, 7(13.7\%) arthropods, 6(11.76\%) reptiles, and 1(1.96\%) species each represented fish and annelids (Kendie et al., 2018). Dereje and Chane (2014) identified a total of 21 animal species, such as mammals, reptiles, and birds to prepare remedies for 46 ailments in the southern part of Ethiopia. Felipe et al. (2013) was also observed the maximum quantity of mammalian species in zootherapeutic activity in Brazil. However, insects occupied the absolute best uses (30.9\%), followed by mammals (23.8\%), fishes (16.7\%), reptiles (11.9\%), amphibians (7.1\%), annelids (4.8\%), and gastropods (4.8\%) during a related study from India (Borah and Prasad, 2017).

From the present study, the local people of the area were utilizing diverse parts/products of animals in the preparation of traditional medicines for the treatment of several diseases. The parts/products of animals categorized in the present study were similar to the ones that were reported by Haileselasie (2012) and Kendie et al. (2018). Additional discoveries also identified that wild animals and livestock, and their by-products such as hooves, skins, bones, feathers, and tusks are vital elements in the preparation of curative, protective, and preventive remedies (Adeola, 1992; Anyinam, 1995; Kang, 2003; Vats and Thomas, 2015). The diverse organs of invertebrates are also used as traditional medicines (Meyer-Rochow, 2017). Out of the diverse body parts of the animals, visceral organs (bile, fat, tongue, juices, liver, rumen, spleen, pancreas) and animal products (egg, milk, butter, cheese, and honey,) have the highest proportion $(N=18,20.45 \%)$, followed by meat $(N=13,14.7 \%)$ used for remedial preparation. However, other similar findings reported flesh with the highest proportion (33.8\%), followed by fat (11.5\%), bone (8.6\%), and blood (8.6\%) (Dereje and Chane, 2014; Kendie et al., 2018).

As shown in the results, remedies were prepared in different ways. Raw used medicines hold the largest share 58(65.90\%) of the total preparation, followed by cooked $9(10.23 \%)$, soup $4(4.55 \%)$, fumigation and roasted (each $3.40 \%$ ), warm and dried (each $3.40 \%$ ), oiled and decoction (each $2.27 \%$ ), and churned 1 $(1.14 \%)$. The medicinal animal species taken as raw for the treatment of ailments is a common method among the tribal communities in Ethiopia as well as at the global level (El-Kamali, 2000; Alves et al., 2010; 2012; Kim and Song, 2013; Dereje and Chane, 2014; Kendie et al., 2018). 
The prepared traditional remedies were administrated through different routes. The oral was the most frequently used route $(N=50,57 \%)$, followed by topical application $(N=18,20 \%)$, tying $(N=9,10 \%)$, nasal $(N=6,7 \%)$, holding $(N=3,3 \%)$, dropping $(N=2,2 \%)$ and wearing $(N=1,1 \%)$. Ready-made solid and liquid medicines were given orally which is in line with other similar studies (Jaroli et al., 2010; Haileselasie, 2012; Kendie et al., 2018). For topical uses still, an important way of remedy administration to treat diseases skeleton muscular system disorder like, rheumatism, paralysis, swellings, and arthritis (Jaroli et al., 2010; Haileselasie, 2012; Kim and Song, 2013; Kendie et al., 2018).

Medicinal fumes were allowed to enter the body through the nose during fumigation operations, and various animal parts, such as bones, skin, and teeth, were considered to have healing properties and were tied to the neck, hand, leg, and other areas of the body. Animal parts, such as bones, skin, and teeth were supposed to be remedy by ligatures on the neck or other parts of the body (Jaroli et al., 2010).

\subsection{Comparison with previous studies}

The better therapeutic and remedial purposes with the animal parts and byproducts to treat different ailments were indicated in the present study (Table 1). For instance, porcupine meat is prescribed for the treatment of bacterial infections, weight gain, swelling, rheumatism, stunting, stomach pain, pleurisy, bone fracture, and malaise. For the treatment of paralysis, stunting, and pleurisy, the soup and bile from an equivalent animal are also used. Tan et al. (2019) and Gomez (2021) reported similar findings from Indonesia and Malaysia, respectively.

Drinking the milk of cows is used for the treatment of gastritis, weight gain, and typhoid. Other similar findings reported an equivalent thing from their study areas (Altaf et al., 2017; Kendie et al., 2018). Most of the time, the inhabitants within the study area prescribe milk to drink if someone took in toxic chemicals in an accident. They believe that the toxic chemicals will throw up (leave) the body as if the patient drinks the milk. This finding is reported for the primary time as completely unique within the present study. Eating raw spleen is used for the treatment of pleurisy and sciatica. At an equivalent time eating liver fresh has a good health-promoting effect especially in anemic-related conditions which are in line with the finding of Kendie et al. (2018). To alleviate a fever associated with malaria, drinking bile or eating in a mixture of prepared foods is a common practice of the local society. In line with this study, the therapeutic uses of animal bile in traditional Chinese medicine are reviewed by Wang and Carey (2014).

Butter is eaten directly or during a mixture with other foods for the treatment of pleurisy, bone fractures, common cold, and weight gain. Other similar findings reiterated the medicinal use of butter in line with this study (Kendie et al., 2018). The appliance of butter on the top of the head is to alleviate a severe headache within the present study is supported by Gemechu and Tola (2017). Placing the fresh butter onto the teeth may help to alleviate teeth ache, and holding inside the auditory meatus is a common practice supposed to support the natural clearing of earwax from an ear and to alleviate otalgia (earache).

Drinking churned milk is used to gain energy and plays a great role in strengthening the teeth especially in children in the present study is supported by the work of Thorning et al. (2016) and Malmir et al. (2019). The part of the leg (below knee, up to hoof) is finely cooked in a large pot for three up to four consecutive days with spices. At that moment, drinking the soup helps to discharge cold and it is a popular treatment for bone fractures and slipped discs in humans. This finding is novel and has not been reported elsewhere despite their golden therapeutic importance.

For the treatment of asthma, pleurisy, and pneumonia the local people have used drinking of raw milk of donkeys which is supported by Schwarcz (2017) and Prasad (2020). Breast milk of humans is used for the treatment of eye disease especially for a child by dropping onto the eye is in line with the findings of Diego et al. (2016). Urinating to the wound allows the wound to become covered by scab during the healing process and speed the recovery. Ramesh et al. (2010) also reported the wound healing activity of human urine.

Taking hair (mow) from the ghul or ghulah (a person with the spirit of the evil eye) and milling, mixing with water then drinking or direct fumigation in fire and smelling the smoking is used for the evil eye (ghoul) treatment. This finding is novel and has not been reported elsewhere, however, it is a commonly practiced means of evil eye treatment in the study area.

One of the novels of the present findings was the fur of the Ethiopian hare is also commonly applied to the wound (robed) so that the scab is formed immediately. No matter how this medication is popular and practiced by the whole community since time immemorial, no reports were identified to support the present work.

For the treatment of rheumatism particularly in the head region, cold, asthma, headache, and skin disease either tying on hand or fumigation, the visceral fat of python is used in the study area. A similar finding has been reported by Klauber (1997), in which the use of fat in the treatment of skin disease and rheumatism.

For the treatment of evil eye, sciatica, and stomach pain, the tongue, and excrement of the spotted hyena are also ingested, and also helps to improve the quality of milk in the livestock. The sole, eyelash, and teeth play a significant role in the treatment of running problems, oversleeping, and lymphadenopathy by handing while walking feels sleeping and tying around the neck, respectively. In line with the present study, different parts of the hyena's body where effective means to various ailments were reviewed by Frembgen (1998).

Drinking fish soup is used for the treatment of cold; the meat and oil are for the treatment of bone fractures, and liver for treatment of eye disease. In line with the present study, other similar studies found that foods rich in omega-3s and calcium, like fish oil has bone-boosting benefits. It was also reported that fishes are a great source of vitamin D, perfect for curing sniffles during cold and flu season (Malde et al., 2010; NPI, 2019; Butler, 2020). 
For the treatment of pleurisy and stomach pain, eating of the larvae of the honey bees is used. Painting honey on the skin is used for the treatment of skin disease and eating in a mixture with garlic, ginger and milk may help to relieve erectile dysfunction (ED) and cold. In line with the present study, other findings reported similar things in their review (Ediriweera et al., 2012; Sforcin et al., 2017).

The meat of sheep is used for weight gain in the present study is in line with the findings of Mohapatra et al. (2019). For the treatment of anemia, fever, energy gain, cold, and any tropical diseases, blood and raw milk of goats drinking is usually used by the local community of the study area. In line with the present study, the nutritional and medicinal value of goat milk is reviewed by Singh (2019). Kakati et al. (2006) reported that tying the skin of the monitor lizard on hand is used for the treatment of cold and rheumatism. Eating the meat of rats was used to relieve stomach pain similar to the fining reported from northern Ethiopia (Kendie et al., 2018).

\subsection{Dosages of remedies}

Overall, there was no standardization among practitioners in the research area when it came to the dosage of medicines. The same animal species with a particular component is administered in different doses for the treatment of related illnesses. Informants still lack consensus on the doses of certain prescriptions and insufficient dosing accuracy, these may be the major drawbacks of traditional medicines. It is well known that certain traditional healers modify dosages and frequency of application based on age, gender, and other conditions, or that the medication itself varies based on such differences.

\section{Conclusion}

The present study is the preliminary survey that tried to gather folk knowledge on the use of animal-based therapies won't by people of Wolaita, Ethiopia The study depicts those animals are still being used by the local practitioners to treat various human and livestock health illnesses. Ethnic communities have adopted their own techniques to prepare traditional remedies. Altogether 39 different animals, their parts, and products used in traditional therapeutics followed by the native people of Wolaita to treat more than 150 different ailments in the study area were described. However, in terms of documentation and evaluation of their therapeutic potential, animal-derived medicines are still a poorly explored field of research, and vital indigenous information is being lost along with the elders and specialists. Scholarly research into the medical uses of animals and their products should not be overlooked and should be viewed as a valuable complementary and alternative medicine. Furthermore, multidisciplinary approaches to fully exploiting the potential of animal medicines/animal products will aid in improving local people's health and spreading awareness about the management and sustainable use of indigenous knowledge, as well as the conservation of bio-resources, as well as providing opportunities for novel drug discoveries.

\section{Recommendations}

The inhabitants in the study area use traditional animal medicine for the treatment of various kinds of ailments. This indicates that traditional medicine plays a significant role in filling the gap in modern health services and help to replace expensive treatment and drugs not available for users nearby. However, some of the practitioners do not have knowledge about zoonotic disease and do not use any protective mechanisms during remedy preparation. Therefore, we recommended the following recommendations:

- It is good to test the health condition of that particular species, before using any animals for therapeutic purposes.

- By using this baseline data for future reference other interested scholars needed to undergo further and detailed study on the analysis of active ingredients and other pharmacological and ethnozoological aspects of animals in Wolaita.

- Comparative study on ethnomedicinal animal population abundance should be conducted at different geographic areas to see the local effect of the traditional medicinal practices.

\section{Limitations}

To capture the whole faunal and cultural cycle of the studied area, the ideal field research would take more than a year. There is also seasonal variation in both illnesses and the availability of treatments. However, covering less than a full year to collect the appropriate data is identified limitation of the present study.

\section{Declarations}

\section{Ethics approval and consent to participate}

The ethics approval is not applicable. The methods of obtaining ethnobiological data followed guidelines set by the International Society of Ethnobiology Code of Ethics for this research (ISE, 2006). Signing papers is simply not common in the study site, therefore, the objective of the research was explained to all respondents in brief and oral prior informed consent was obtained before the interviews. All work conducted was carried out under the stipulations of the Nagoya Protocol on Access to Genetic Resources and the fair and equitable Sharing of Benefits Arising from their Utilization to the Convention on Biological Diversity. The right to use and authorship of any traditional knowledge of all participants is maintained, and any use of this information, other than for scientific publication, does require the additional prior consent of the traditional owners, as well as a consensus on access to benefits resulting from subsequent use.

\section{Consent for publication}

This manuscript doesn't contain any person's data, and further consent for publication isn't required. 
Availability of data and materials

The data generated and analyzed during the current study are included in the body of this paper.

Competing interests

There is no conflict of interest between the authors regarding this paper.

\section{Funding}

The study did not obtain any particular funding from finance organizations in the public, commercial, or not-for-profit sectors.

\section{Authors' contributions}

Abenezer Wendimu: Designed the research, collected data, organized the data on the computer, did the analysis, interpretation, and identification, and wrote the draft manuscript.

Wondimagegnehu Tekalign: Proposed the research conception, read the draft, review, and edit, supervised; and validated the final manuscript.

\section{Acknowledgments}

We are very much grateful to all volunteers involved in data collection and all the respondents who shared their traditional zootherapeutic knowledge; without their contribution, this study would have been impossible. Finally, we would like to extend our gratitude to Wolaita Sodo University for their permission to do this research work.

\section{Abbreviations}

- NPI: National Fisheries Institute

- ISE: International Society of Ethnobiology

- PRA: Participatory Rural Appraisal

- THP: Traditional Health Practitioners

- WHO: World Health Organization

\section{References}

Adeola, M.O., 1992. Importance of wild animals and their parts in the culture, religious festivals and traditional medicines of Nigeria. Environ. Conserv. 19, 125-34. https://www.jstor.org/stable/44518690

Alevtina, G., Zerihun, S., 2009. Ethiopian traditional and herbal medications and their interactions with conventional drugs. http://ethnomed.org/clinical/pharmacy/ethiopian-herb-drug-interactions (accessed 16 June 2021).

Alexiades, M.N., 1996. Selected guidelines for ethnobotanical research: a field manual. New York Botanical Garden, New York.

Ali, S., 1996. The book of Indian birds. Bombay Natural History Society, Bombay.

Altaf, M., Javid, A., Umair, M., Iqbal, K.J., Rasheed, Z., Abbasi, A.M., 2018. Ethnomedicinal and cultural practices of mammals and birds in the vicinity of river Chenab, Punjab-Pakistan. J. Ethnobiol. Ethnomed. 13, 41. https://doi.org/10.1186/s13002-017-0168-5.

Alves, R.R., Souto, W.M. 2011. Ethnozoology in Brazil: current status and perspectives. J. Ethnobiol. Ethnomed. 7, 22. https://doi.org/10.1186/1746-4269-722.

Alves, R.R.N., Neta, R.O.S., Trovão, D.M.B., Barbosa, J.E.L., Barros, A.T., Dias, T.L.P., 2012. Traditional uses of medicinal animals in the semi-arid region of northeastern Brazil. J. Ethnobiol. Ethnomed. 8, 41. http://dx.doi.org/10.1186/1746-4269-8-41

Alves, R.R.N., Oliveira, M.G.G., Barboza, R.R.D., Lopez, L.C.S., 2010. An ethnozoological survey of medicinal animals commercialized in the markets of Campina Grande, NE Brazil. Hum. Ecol. Rev. 17(1). https://doi.org/10.1007/s10745-009-9295-5

Alves, R.R.N., Rosa, I.L., Santana, G.G., 2007. The role of animal-derived remedies as complementary medicine in Brazil. Bioscience 57(11), 949-955.

https://doi.org/10.1641/B571107

Anyinam, C. 1995. Ecology and ethnomedicine: exploring links between current environmental crisis and indigenous medical practices. Soc. Sci. Med. 40, 321-9. https://doi.org/10.1016/0277-9536(94)E0098-

Assegid, A., Tesfaye, A., 2014. Ethnobotanical study of wild medicinal trees and shrubs in Benna Tsemay district, southern Ethiopia. J. Sustain. Dev. 2(1), 17-33. [Google scholars] 
Bekele, A., Yalden, W., 2013. Mammals of Ethiopia and Eritrea. Addis Ababa University Press, Addis Ababa.

Borah, M.P., Brasad, S.B., 2017. Ethnozoological study of animals based medicines used by traditional healers and indigenous inhabitants in the anointing area Gibbon Wildlife Sanctuary, Assam, India. J. Ethnobiol. Ethnomed. 13, 39. https://dx.doi.org/10.1186\%2Fs13002-017-0167-6

Butler, N., 2020. 7 best foods for healthy eyes. Health line media. https://www.healthline.com/health/eye-health/best-foods-for-eyes (accessed 22 June 2021).

Chakravorty, J., Meyer-Rochow, V.B., Ghosh, S., 2011. Vertebrates used for medicinal purpose by members of Nyishi and Galo tribes in Arunachal Pradesh (North-East India). J. Ethnobiol. Ethnomed.7, 13. https://doi.org/10.1186/1746-4269-7-13.

Dereje, D.W., Chane, M., 2014. Ethnozoological study of traditional medicinal animals used by the Kore people in Amaro woreda, Southern Ethiopia. Int. J. Mol. Evol. Biodivers. 4(2), 1-9. https://doi.org/10.5376/ijmeb.2014.04.0002

Diego, J.L., Bidikov, L., Pedler, M.G., Kennedy, J.B., Quiroz-Mercado, H., Gregory, D.G., Petrash, J.M., McCourt, E.A., 2016. Effect of human milk as a treatment for dry eye syndrome in a mouse model. Mol. Vis. 22, 1095-1102. PMID: 27667918; PMCID: PMC5017541.

Ediriweera, E.R., Premarathna, N.Y., 2012. Medicinal and cosmetic uses of bee's honey - a review. Ayu. 33(2), 178-182. https://doi.org/10.4103/09748520.105233

Elias, A.S., Tesfaye, G., Bizatu, M., 2013. Aspects of common traditional medical practices applied for under-five children in Ethiopia, Oromia Region, EasternHarargie district, Dadar woreda, 2011 G.C. J. Community Med. Health Educ. 3, 6. https://doi.org/10.4172/2161-0711.1000237

El-Kamali, H.H., 2000. Folk medicinal use of some animal products in Central Sudan. J. Ethnopharmacol. 72, 279-282. http://dx.doi.org/10.1016/S03788741(00)00209-9

Felipe, S.F., Hugo, F., Nivaldo, Samuel, V., Rômulo, RNA., 2013. The trade of medicinal animals in Brazil: current status and perspectives. Biodivers. Conserv. 22, 839-870. https://doi.org/10.1007/s10531-013-0475-7

Frembgen, W.J., 1998. The magicality of the Hyena: beliefs and practices in west and south Asia. Asia. Folk. Stud. 57(2), 331-344. https://doi.org/10.2307/1178757

Gemechu, A.T., Tola, Y.B., 2017. Traditional butter and ghee production, processing and handling in Ethiopia: A review. Afr. J. Food Sci. 11(4), 95-105. https://doi.org/10.5897/AJFS2016.1544

Giday, M., Asfaw, Z., Elmqvist, T., Woldu, Z., 2003. An ethnobotanical study of medicinal plants used by the Zay people in Ethiopia. J. Ethnopharmacol. 85(1), 43-52. https://doi.org/10.1016\%2Fj.jep.2010.07.046

Gomez, L., 2021. The illegal hunting and exploitation of porcupines for meat and medicine in Indonesia. Nat. Conserv. 43(1), $109-122$. https://doi.org/10.3897/natureconservation.43.62750

Hailemariam, T., Demissew, S., Asfaw, Z., 2009. An ethnobotanical study of medicinal plants used by local people in the lowlands of Konta special woreda, southern nations, nationalities and people's regional state, Ethiopia. J. Ethnobiol. Ethnomed. 5, 26. https://doi.org/10.1186/1746-4269-5-26.

Haileselasie, T., 2012. Traditional zootherapeutic studies in Degu'aTembien, Northern Ethiopia. Curr. Res. J. Biol. Sci. 4(5), 563-569. [Google scholars] Holzman, D., 2003. Meat eating is an old human habit. New Scientist 179. https://www.newscientist.com/article/mg17924112-300-meat-eating-is-an-oldhabit/ (accessed 09 June 21).

Huntington, H.P., 2000. Using traditional ecological knowledge in science: methods and applications. Ecol. Appl. 110, 1270-4. https://doi.org/10.1890/10510761(2000)010[1270:UTEKIS]2.0.CO;2

International Society of Ethnobiology (ISE), 2006, International Society of Ethnobiology Code of Ethics (with 2008 additions). http://ethnobiology.net/codeof-eth

Jaroli, D.P., Mahawar, M.M., Vyas, N., 2010. An ethnozoological study in the adjoining areas of Mount Abu wildlife sanctuary, India. J. Ethnobiol. Ethnomed. 6, 6. https://doi.org/10.1186/1746-4269-6-6

Kakati, L.N., Ao, B., Doulo, V., 2006. Indigenous knowledge of zootherapeutic use of vertebrate origin by the Ao Tribe of Nagaland. J. Hum. Ecol. 19(3), 163167. https://doi.org/10.1080/09709274.2006.11905874.

Kang, S., Phipps, M., 2003. A question of attitude: South Korea's traditional medicine practitioners and wildlife conservation. Hong Kong: Traffic East Asia. http://www.rhinoresourcecenter.com/index.php?s=1\&act=refs\&CODE=ref_detail\&id=1187862086 (accessed 24 June 21).

Kendie, F.A., Mekuriaw, S.A., Dagnew, M.A., 2018. Ethnozoological study of traditional medicinal appreciation of animals and their products among the indigenous people of Metema Woreda, North-Western Ethiopia. J. Ethnobiol. Ethnomed. 14, 37 https://doi.org/10.1186/s13002-018-0234-7. 
Keter, L.K., Mutiso, P.C., 2012. Ethnobotanical studies of medicinal plants used by traditional health practitioners in the management of diabetes in lower eastern province: Kenya. J. Ethnopharmacol. 139, 74-80. https://doi.org/10.1016/j.jep.2011.10.014

Kim, H., Song, M.J., 2011. Analysis and recordings of orally transmitted knowledge about medicinal plants in the southern mountainous region of Korea. J. Ethnopharmacol. 134, 676-96. https://doi.org/10.1016/j.jep.2011.01.024

Kim, H., Song, M.J., 2013. Ethnozoological study of medicinal animals on Jeju Island,Korea. J. of Ethnopharmacol. 146, 75-82.

https://doi.org/10.1016/j.jep.2012.11.011

Klauber, L.M., 1997. Rattle snakes, vol II. University of California Press. pp. 1050. [Google scholars]

Larsen, C.S., 2003. Animal source foods and human health during evolution. J. Nutr. 133, 3893-3897. https://doi.org/10.1093/jn/133.11.3893S

Lawrence, E.A., 2003. The Mythical Zoo: an encyclopedia of animals in world myth, legend, and literature Boria Sax. Anthrozoös 16 (3), $282-286$.

https://doi.org/10.2752/089279303786992080

Lev, E., Amar, Z., 2000. Ethnophrmacological survey of traditional drugs sold in Israel at the end of the 20th century. J. Ethnopharmacol. $72,191-205$.

https://doi.org/10.1016\%2FS0378-8741(00)00230-0

Malde, M.K., Bügel, S., Kristensen, M., Malde, K., Graff, I.E., Pedersen, J.I., 2010. Calcium from salmon and cod bone is well absorbed in young healthy men: a double-blinded randomized crossover design. Nutr. Metab. 7, 61. https://doi.org/10.1186/1743-7075-7-61

Malmir, H., Larijani, B., Esmaillzadeh, A., 2020. Consumption of milk and dairy products and risk of osteoporosis and hip fracture: a systematic review and meta-analysis. Crit. Rev. Food Sci. Nutr. 60(10), 1722-1737. https://doi.org/10.1080/10408398.2019.1590800

Melesse, M., Sileshi, N., Tamirat, B., 2015. An ethnobotanical study of medicinal plants of the Kembatta ethnic group in Enset-based agricultural landscape of Kembatta Tembaro (KT) zone, southern Ethiopia. Asian J. Plant Sci. 5(7), 39-61. https://www.pelagiaresearchlibrary.com

Meyer-Rochow, V.B., 2017. Therapeutic arthropods and other, largely terrestrial, folk medicinally important invertebrates: a comparative survey and review. J. Ethnobiol. Ethnomed.13, 9. https://doi.org/10.1093/ecam/neh057

Mohapatra, A., Shinde, A.K., Singh, R., 2019. Sheep milk: a pertinent functional food. Small Rumin. Res.

181(5).https://doi.org/10.1016/j.smallrumres.2019.10.002

National Fisheries Institute (NPI), 2019. Seafood to keep you healthy during cold \& flu season. https://dishonfish.com/seafood-to-keep-you-healthy-duringcold-flu-season/ (accessed 22 June 2021).

Oliveira, E.S., Torres, D.F., Brooks, S.E., Alves, R.R.N., 2010. The medicinal animal markets in the metropolitan region of Natal City, Northeastern Brazil. J. Ethnopharmacol. 130, 54-60. https://doi.org/10.1016/j.jep.2010.04.010

Prasad, B., 2020. Nutritional and Health Benefits of Donkey Milk. J. Food Sci. Nutr. The. 6(1): 022-025. http://doi.org/10.17352/jfsnt.000022.

Ramesh, H.A., Azamthulla, M., Baidya, M., Mohammed, A., 2010. Wound healing activity of human urine in rats. Res. J. Pharm. Biol. Chem. Sci. 1(3), 750758. [Google scholars]

Regassa, R., 2013. Assessment of indigenous knowledge of medicinal plant practice and mode of service delivery in Hawassa city, southern Ethiopia. J. Med. Plant Res. 7(9), 517-35. https://doi.org/10.5897/JMPR12.1126

Ripple, W.J., Newsome, T.M., Wolf, C., Dirzo, R., Everatt, K.T., Galetti, M., Hayward, M.W., Kerley, G.I.H., Levi, T., Lindsey, P.A., Macdonald, D.W., Malhi, Y., Painter, L.E., Sandom, C.J., Terborgh, J., Valkenburgh, B., 2015. Collapse of the world's largest herbivores. Sci. Adv. 1, e1400103.

https://doi.org/10.1126/sciadv.1400103

Schwarcz, J., 2017. Leave the donkey milk to the donkeys. Office for science and society. McGill University. https://www.mcgill.ca/oss/article/healthhistory/leave-donkey-milk-donkeys (accessed 21 June 2021).

Serpell, J., 1996. In the company of animals: A study of human-animal relationships. Cambridge University Press. [Google scholars]

Sforcin, J.M., Bankova, V., Kuropatnicki, A.K., 2017. Medical benefits of honeybee products. Evid Based Complement Alternat Med. 2017:2702106.

https://doi.org/10.1155/2017/2702106

Singh, R., 2019. Nutritional and medicine value of goat milk. https://www.pashudhanpraharee.com/nutritional-medicinal-value-of-goat-milk/ (accessed 22 June 2021).

Tan, C.S., Ng, C.H., Chun, L.Y., Yam, F.M., 2019. A traditional folk medicine in Malaysia: porcupine bezoar. Orient. Pharm. Exp. Med. 19:131. https://doi.org/10.1007/s13596-019-00370-4 
Tefera, N., Kim, Y., 2019. Ethnobotanical study of medicinal plants in the Hawassa zuria district, Sidama zone, southern Ethiopia. J. Ethnobiol. Ethnomed. 15, 25. https://doi.org/10.1186/s13002-019-0302-7

Thorning, T.K., Raben, A., Thorning, T., Soedamah-Muthu, S.S., Givens, I., Astrup, A., 2016. Milk and dairy products: good or bad for human health? An assessment of the totality of scientific evidence. Food Nutr. Res. 60:32527. https://doi.org/10.3402/fnr.v60.32527

Tuasha, N., Petros, B., Asfaw, Z., 2018. Medicinal plants used by traditional healers to treat malignancies and other human ailments in Dalle district, Sidama zone, Ethiopia. J. Ethnobiol. Ethnomed. 14, 15. https://doi.org/10.1186/s13002-018-0213-z

Vats, R., Thomas, S., 2015. A study on use of animals as traditional medicine by Sukuma Tribe of Busega District in North-western Tanzania. J. Ethnobiol. Ethnomed. 11, 38. https://doi.org/10.1186/s13002-015-0001-y

Wang, D.H.Q., Carey, M.C, 2014. Therapeutic uses of animal biles in traditional Chinese medicine: an ethnopharmacological, biophysical chemical and medicinal review. World J. Gastroenterol. 20(29), 9952-9975. https://doi.org/10.3748/wjg.v20.i29.9952

Wendimu, A., Tekalign, W., 2020. Infusion extraction of toxin from chili pepper (Capsicum baccatum) for bedbug protection. Asian J. Biotechnol., 12 : 65-74. https://doi.org/10.3923/ajbkr.2020.65.74

Wendimu, A., Tekalign, W., Asfaw, B., 2021. A survey of traditional medicinal plants used to treat common human and livestock ailments from Diguna Fango district, Wolaita, southern Ethiopia. Nord. J. Bot. 39(5), 1-20. https://doi.org/10.1111/njb.03174

Whiting, M.J., Williams, V.L., Hibbitts, T.J., 2010. Animals traded for traditional medicine at the Faraday market in South Africa: species diversity and conservation implications. J. Zool. 284, 84-96. https://doi.org/10.1111/j.1469-7998.2010.00784.x

World Health Organisation (WHO), 1993. Guidelines on conservation of medicinal plants. Gland, Switzerland. [Google scholars]

Wolf, C., Ripple, W.J., 2016. Prey depletion as a threat to the world's large carnivores. R. Soc. Open Sci. 3160252160252.

http://doi.org/10.1098/rsos.160252.

Yirga, G., Teferi, M., Gebreslassea, Y., 2011. Ethnozoological study of traditional medicinal animals used by the people of Kafta-Humera District, Northern Ethiopia. Int. J. Med. Med. Sci. 3(10), 316-320. https://doi.org/10.5897/IJMMS.9000100.

\section{Figures}

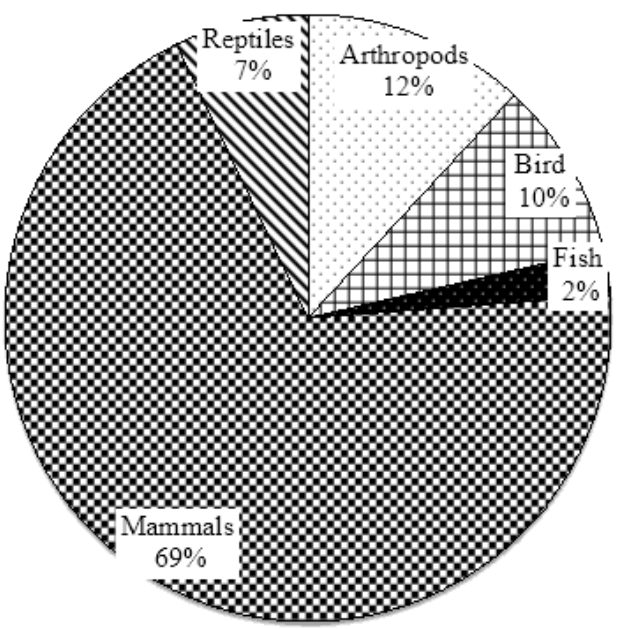

Figure 1

Classification of animals and number of species used for zootherapy in the study site 


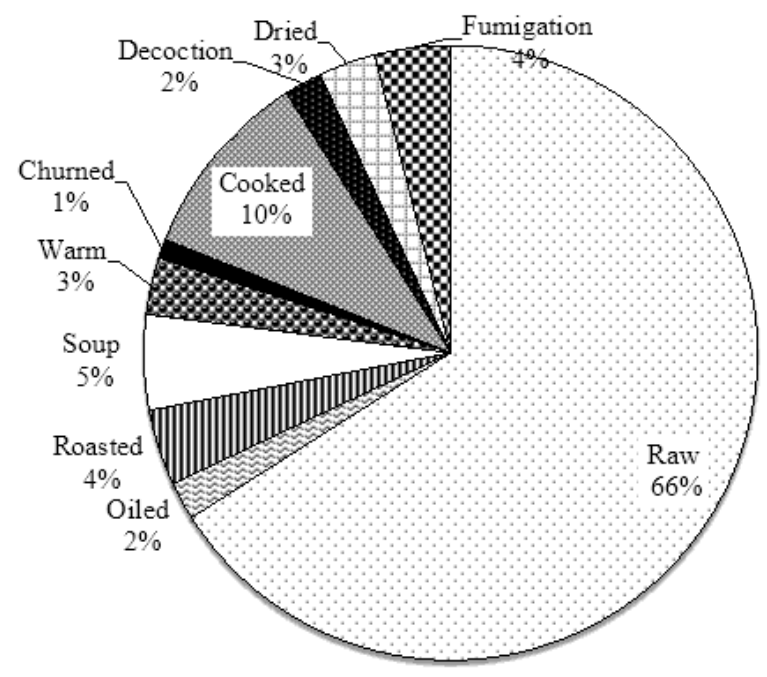

Figure 2

Ways of remedy preparation

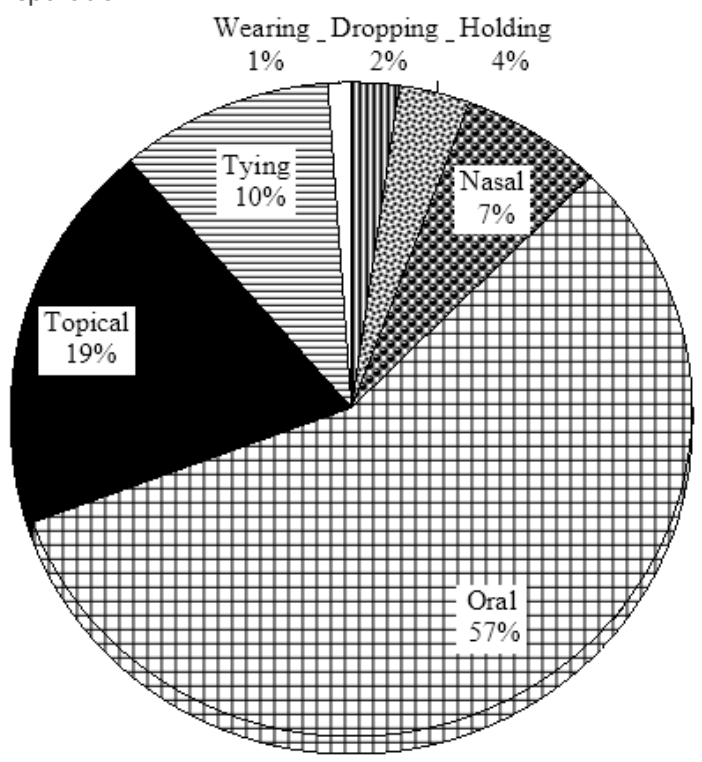

Figure 3

Application routes 